\title{
$\widehat{A}$ Madridge \\ madridge Journal of Nursing
}

Interconnecting Scientific World

Research Article

Open Access

\section{Risk taking Behaviors and the related Factors among Female Adolescents' Student enrolled in the Secondary Schools}

\author{
Lamia A Salama ${ }^{1}$, and Awateef Elsayed ${ }^{2 \star}$ \\ ${ }^{\prime}$ Department of Community Health Nursing, College of nursing, Mansoura University, Egypt \\ ${ }^{2}$ Associated Professor, Pediatric Nursing, Dammam University, Saudi Arabia
}

\section{Article Info}

\author{
*Corresponding author: \\ Awateef Elsayed \\ Associated Professor \\ Pediatric Nursing \\ Dammam University \\ Saudi Arabia \\ E-mail: awelsayed@uod.edu.sa
}

\section{Received: April 4, 2017}

Accepted: May 1, 2017

Published: May 8, 2017

Citation: Salama LA, Elsayed A. Risk taking Behaviors and the related Factors among Female Adolescents' Student enrolled in the Secondary Schools. Madridge J Nurs. 2017; 2(1): 34-43.

doi: $10.18689 / \mathrm{mjn}-1000107$

Copyright: (c) 2017 The Author(s). This work is licensed under a Creative Commons Attribution 4.0 International License, which permits unrestricted use, distribution, and reproduction in any medium, provided the original work is properly cited.

Published by Madridge Publishers

\begin{abstract}
Background: Risk taking behavior refers to the tendency to engage in behaviors that have the potential to be harmful or dangerous, which has become a major concern and is rated as one of the public health issues that need special attention.
\end{abstract}

Aim: The aim of this study was to identify the common risk taking behaviors and related factors among female adolescents students enrolled in the secondary schools at Mansoura city -Dakahlia Governorate.

Design: Across-sectional study was conducted.

Sample: A representative sample of schools was selected using the multistage stratified random sampling technique, the total number of selected schools was 6 schools The sample size was proportionally allocated according to the type of education, and the three educational districts, and it represented the 1st .the 2 nd and the 3rd grades and the classes in selected schools were also selected randomly according to the estimated number of students $(n=1070)$.

Tools: Four tools were used to collect data. 1) Students profile as demographic characteristics, biological, social, educational and relationships. 2) The short Arabic Version of Cooper Smith Self Esteem Inventory [14]. 3) The Arabic Form of Tayber Manifest Anxiety Scale [15] and 4) The Arabic Translation of Beck's Depression Inventory [16].

Results: Prevalence of risk taking behaviors (RTB) as responded by adolescents' students, it was found that $72.9 \%$ of students responded they didn't practice risk taking behavior, $18.3 \%$ practicing one type only of RTB. while $8.8 \%$ of them practicing more than one type of RTB, $17.8 \%$ responding domestic violence, $8.5 \%$ of them illicit sexual relation and $7.4 \%$ reported smoking. Students who practicing RTB have low self-esteem than others $(54.8 \%$ and $49.4 \%$ respectively with no statistical significant difference. Students who practicing RTB responded that they didn't ask for advice, they search for knowledge related RTB and practicing unplanned activities as Internet café for chatting, unsupervised walking in groups, driving cars without license or teasing other sex. $\mathrm{P}=0.001$.

Conclusion and recommendation: This study helps to identify the high risk groups which are in need of special attention and necessitates the design of interventions particularly by educators and program providers. The factors which are significantly associated with adolescent RTB were; family structure, satisfaction of adult adolescent relationship, educational zones, scholastic achievement, peers adoption of RTB, asking for advice and practicing of unplanned activities.

Keywords: Risk taking behavior (RTB); Smoking; Substance abuse: Domestic violence; Illicit sexual relation. 


\section{Introduction}

Adolescence is a time of many changes, some of which are subtle and some are apparent. Several changes take place simultaneously during the adolescence phase, some impacting there thinking, emotions and behavior more than others. No aspect of adolescent development has received more attention from public and researcher than parent adolescent relationship. Much of the research indicated that despite altered pattern of interaction, relationship with parent remain important social and emotional resources well beyond the childhood years [1]. Up until the present it is a challenge to reconcile this conclusion with the widespread perception that parent - adolescent relationships decline in quality and influence over the course of the adolescent years. In general, it may be observed that the adolescence period has been and continues to be considered a different time of life for main these reasons: 1) There is little opportunity to participate in an inherently meaningful activity, as the culture of the young is riddled with hypocrisy and short - term goals. 2) The school setting in which they spend most of their waking hours tends to reinforce artificial rules of acceptance and over reliance and on conformity [2].

Available evidence suggests that adolescents engage in variety of risky behaviors, including smoking, alcohol and drug use and abuse, poor diets and sedentary lifestyles, which leads to overweight and obesity, vehicular speeding, lack of seatbelt use, and risky sexual behavior [3], which make them susceptible to serious physical and mental problems. In addition, these behaviors contribute to educational and social problems among students [4]. Topolski et al., 2011, stated that the use and misuse of alcohol, drugs and sexual behavior contribute to social problems, morbidity and mortality. Numerous theorists have sought to explain who is most likely to initiate health-risk behaviors. These theories have focused on risk-taking as a normal developmental behavior, psychological correlates such as self-esteem, and contextual correlates such as peers and neighborhood [5].

\section{Review of Literature}

Risk taking behavior refers to the tendency to engage in behaviors that have the potential to be harmful or dangerous, which has become a major concern and is rated as one of the public health issues that need special attention $[6,7]$.

Risky health behaviors that arise during adolescence have a serious impact on the health and development of adolescents and young people's current health status, and increased risk for developing chronic diseases in adulthood. In addition, they are considered as a major source of preventable premature deaths [8].

According to CAPMAS (2015) Adolescents (ages 10 to 19 years) make up 9.7\%, $4.7 \%$ male and female of the population in Egypt [9].

The study of adolescence Risk Taking Behavior is of great concern to health professionals as much of the adverse health consequences experienced by adolescents are to a large extent the result of risk behaviors [4]. These behaviors include tobacco use, alcohol and other drug use, violence and sexual behaviors [6]. Every year, an estimated 1.7 million of those in the second decade lose their life, mostly through accidents, suicide. Violence, pregnancy related complications and other illness that was behavioral in origin and are either preventable or treatable. WHO estimates that $70 \%$ of premature deaths among adults are largely due to behaviors initiated during adolescents and remain as major contributors to the health problems among adolescent. As successful preventive efforts have been noted among adults but not in adolescents, recently, WHO has been advocating and promoting attention on adolescents [7].

Parents of adolescents are often blamed for the risk taking behavior of their children. In some courts of other countries, parents are even penalized for the antisocial conduct of their child. This is because behavior of adolescents is believed to be influenced by family environment and the characteristics of the family [10].

Many researchers agree that the foundation of the adolescent risk behavior is rooted in the kind of home that the adolescent has been brought up in. The family, which is the smallest unit in the society, needs to be charged with positive values to ensure family members are growing up in a conducive environment, so that they can face the outside world problems appropriately. The family plays an important role in the development of children's values, conception of individuality, and the way of coping with real life. By action and by example, parents shape the lives of their children from birth through adulthood [11].

In adolescents, the influence of friends and peers takes on greater importance, but research clearly demonstrates the continued significance of parents in shaping the behavior and choices of teens as they face the challenges as they grow up. There are various factors in the family that facilitate children's values, self-construal, and resilient behavior. These factors are elements in the family such as the closeness between the child and parents or parent-child interaction, parenting styles, family environment, and the general background of parents. Family conflicts or cohesion would affect the adolescents' behavior and development [12].

One developmental concept describes adolescent ego as having subcategories of the imaginary audience (Elkind, 1978) [13], apparent hypocrisy, pseudo-stupidity and the personal fable. The personal fable has been suspected of underlying a lot of adolescent problem behavior. This highlights that risktaking could have both individual and group characteristics, with these being used to provide a label: 'Certain risks, or patterns of risks, are symbolic of certain kinds of social identity. Worn like badges risks are declarations of the self $[14,15]$.

These facts highlight the essentiality to search and the urgency to understand the situational factors influencing the engagement of risk taking behavior; more particularly, of family characteristic attributes such as family environment, parenting style, and parent-child interaction. There is also minimal study comparing living location and the risk taking 
behavior among adolescents [16].

Preventing adolescent risky behaviors is important for several reasons. One is that engaging in a risky behavior can set the stage for engaging in other risky behaviors, thus increasing the likelihood of self-injury, victimization by others, and other negative consequences that result from risky behaviors. Another reason is that consistently engaging in even one type of risky behavior can undermine progress toward positive educational goals, such as graduating high school on time and can increase the likelihood that social, behavioral, physical, and mental health problems will develop later in life. Substance abuse has been linked to higher rates of cognitive difficulties, isolation, stealing, cutting class, and aggressive behavior. Illicit drug use, in general, has been found to heighten the likelihood of engaging in risky sexual behavior, delinquency, crime, and drug abuse, as well as to increase the risk of injury and death resulting from motor vehicle accidents $[16,17]$.

According to National Institute on Drug Abuse and Child Trends Data Bank (2012, 2015), Aggression and delinquency have been found to predict lower levels of educational attainment and higher levels of mental health, substance abuse, and economic problems. Risky sexual behavior places youth in danger of acquiring sexually transmitted infections, having an unintended pregnancy, and becoming a teen parent. Moreover, engaging in multiple risky behaviors further elevates the likelihood of poor outcomes $[18,19]$.

\section{Significance of the problem}

This study provided accurate and appropriate systematic assessment of health-risk behaviors among adolescent students aged 15 to 19 years. Identification of these risk behaviors is essential for health care professionals and counselors in students' schools to understand the nature of risk behaviors, and to plan better for early interventions. This information might help health care professionals to develop interventional programs that focus on improving students' health, and to implement cultural specific intervention and health promotion programs. Therefore, the purpose of this study was to assess the patterns of health-risk behaviors, namely, diet, physical activity, and tobacco use of the Egyptian adolescent students aged 15 to 19 years old.

\section{Aim of Study}

To identify the common risk taking behaviors and related factors among female adolescent's students enrolled in the secondary schools at Mansoura city -Dakahlia Governorate.

\section{Research design}

Cross sectional research design was selected to fulfill the aims of the research by conducting a school based cross sectional survey in Mansoura City - Dakahlia governorate.

\section{Research Questions}

1. What are the common risk taking behaviors among female adolescents in the secondary schools at Mansoura city?

2. What are the factors related to the risk taking behaviors among female adolescents in the secondary schools at Mansoura city?

\section{Subjects and Method}

Setting: This study was conducted in secondary schools at Mansoura City -Dakahlia Governorate.

Sample: -A representative sample of schools was selected using the multistage stratified random sampling technique. A list of secondary schools, general and technical for girls in three Mansoura educational districts, was obtained from the local directorate of education, Dakahlia governorate. From every district, two schools were selected randomly: one general school and one technical school for girls. Hence, the total number of selected schools was 6 schools. The sample size was estimated using the following equation $n=\left(z 2{ }^{*} p{ }^{*} q\right) / D 2$. As the actual prevalence of risk behaviors is unknown, the probability of its occurrence was estimated to be equal to that of its non-occurrence $(p=q=0.5)$ A value of 0.03 was chosen as the acceptable limit of precision (D) at $95 \%$ confidence intervals where $z=1.96$. Based on these assumptions, the sample size was estimated to be nearly 1070 students. The sample size was proportionally allocated according to the type of education, and the three educational districts, and it represented the 1st .the 2 nd and the 3 rd grades and the classes in selected schools were also selected randomly according to the estimated number of students. Data was collected from the beginning of February to the end of March (Three days per week during the break and activity time, in academic year 2014-2015).

\section{Tools: four tools were used to collect data of the present study:}

1. A specially designed self-administered anonymous questionnaire was developed by the researchers and used to collect data. This tool was preferred than interview to encourage active participation to assure the absolute confidentiality and to give the chance for the real reporting of the undesirable behaviors. It included students profile as demographic characteristics, biological, social, educational and relationships.

2. The short Arabic Version of Cooper Smith Self Esteem Inventory [19].

3. The Arabic Form of Tayber Manifest Anxiety Scale [20].

4. The Arabic Translation of Beck's Depression Inventory [21].

\section{1-The short Arabic Version of Cooper Smith Self Esteem Inventory [19].}

The Coppersmith Self-Esteem Inventories School form (CSEI- SC).The inventory was originally designed to measure children's self-esteem and demonstrates the relationship of academic achievement to personal satisfaction in school 58-items measure attitudes toward one self. For each item, participants answer whether the statement provided is "like 
me" or "not like me". Students asked, if a statement describes how she usually feel, put on X in the column "Like Me." If the statement does not describe how she usually feels, put an X in the column "Unlike Me." There is no right or wrong answers.

\section{Scoring}

The test has a built-in "lie scale" to help determine if participants are trying too hard to appear to have high selfesteem. If they answered "like me" to three or more of the following items, retake the test with an eye toward being more realistic in their responses: $1,6,13,20,27,34,41$, and 48 . To calculate the score, add up the number of times participants responses match those given below. To determine how participant level of self-esteem compares to that of others, find the value closest to her score in the table.

Like me: Items 2, 4, 5, 10, 11, 14, 18, 19, 21, 23, 24, 28, 29, 32, $36,45,47,55,57$

Unlike me: Items $3,7,8,9,12,15,16,17,22,25,26,30,31,33$, $35,37,38,39,40,42,43,44,46,49,50,51,52,53,54,56,58$

\begin{tabular}{|c|c|}
\hline Score & Meaning \\
\hline 32 & Significantly below average \\
\hline 35 & Somewhat below average \\
\hline 39 & Average \\
\hline 43 & Somewhat above average \\
\hline 49 & Significantly above average \\
\hline
\end{tabular}

Low self-steam was scored below 39.

High self-steam was scored 39 and above.

\section{2-The Arabic Form of Tayber Manifest Anxiety Scale [20].}

Is a test of anxiety consisted of 50 true or false questions a person answers by reflecting on themselves, in order to determine their anxiety level. Scoring is easily accomplished by summing scores for items. The total score ranges from $0-63$. The following guidelines are recommended for the interpretation of scores: $0-9$, normal or no anxiety; $10-18$, mild anxiety; $19-29$, moderate anxiety; and $30-63$, severe anxiety.

\section{3-The Arabic Translation of Beck's Depression Inventory (BDI) [21].}

The scale for the BDI was originally created for descriptions of personal symptoms as mood, pessimism, sense of failure, self-dissatisfaction, guilt, suicidal ideas, crying, irritability, social withdrawal, insomnia, fatigue, appetite, weight loss, and self-accusation. In the first portion of the test, psychological symptoms are assessed whereas the second portion assesses physical symptoms. This test includes a 21 item self-report using a four-points Likert's scale ranging which ranges from 0 (symptom not present) to 3 (symptom very intense. The test was taken approximately 5 to 10 minutes to complete.

The score for each of the twenty-one questions by counting the number to the right of each question which marked by the students. The highest possible total for the whole test would be sixty-three. This would mean you circled number three on all twenty-one questions. Since the lowest possible score for each question is zero, the lowest possible score for the test would be zero. This would mean you circles zero on each question. You can evaluate your depression according to the Table below.

\begin{tabular}{|c|c|}
\hline Total Score & Level of depression \\
\hline $1-10$ & These ups and downs are considered normal \\
\hline $11-16$ & Mild mood disturbance \\
\hline $17-20$ & Borderline clinical depression \\
\hline $21-30$ & Moderate depression \\
\hline $31-40$ & Severe depression \\
\hline Over 40 & Extreme depression \\
\hline
\end{tabular}

Low depression scored less than 21

High depression scored 21 and above

\section{Method of Data Collection}

1. Formal approval was obtained from the central Agency for Public Mobilization and Statistics (APMAS) in Cairo and the directorate of education with its seven affiliated sub directorate in Dakahlia governorate.

2. Approval of the schools mangers and class teachers and the students participated in the study sample were obtained after explanation of the study purposes and reassure that the collected data will be confidential and used for the purpose of the study.

3. Pilot study was carried out on 10 adolescents for testing the clarity of the sheets and to estimate the time needed to apply the scale and fulfill the sheet. Adolescents included in the pilot study were excluded from the study.

4. All students were assured that the study would be conducted anonymously to protect their confidentiality. They were also informed that their participation was voluntary, and that not taking part in this study would not affect them in anyway. The questionnaires were distributed to all students by the researcher. The questionnaire was filled by students in front of the researcher to clarify any statements not clear to the students and collected before they left the session. Students asked to fill the sheets individually (each sheet took 10-15 minutes).

\section{Analysis of Data:}

Collected data was coded, analyzed and tabulated using statistical package for social science (SPSS) version 17.0. The $5 \%$ level of significance was chosen.

Analysis of bivariate and multivariate logistic regression was done for statistical association between risk taking behaviors and related factors. The multiple logistic regression models were used to explain and predict the presence or absence of Risk Taking Behavior. The practicing of Risk Taking Behavior was 
the dependent variable. The chosen independent variables were psychological tests namely; anxiety and depression scales, family structure, satisfaction of the relations with both parents and teachers, type of education, educational districts, history of scholastic failure, peers' practicing of Risk Taking Behavior, asking for advice and practicing unplanned activities.

\section{Results}

Table 1: Prevalence of Risk Taking Behaviors (RTB) as Responded by Adolescents' Students.

\begin{tabular}{|l|c|c|}
\hline \multicolumn{1}{|c|}{ Items } & $\begin{array}{c}\text { Number of } \\
\text { students } \\
\mathrm{N}=1070\end{array}$ & $\%$ \\
\hline Didn't practice risk taking behavior & 780 & $72.9 \%$ \\
Practicing one type of risk taking behavior & 196 & $18.3 \%$ \\
Practicing more than one type of risk taking behavior & 94 & $8.8 \%$ \\
- Prevalence of smoking & 79 & $7.4 \%$ \\
- Prevalence of substance abuse & 66 & $6.2 \%$ \\
- Prevalence of domestic violence & 190 & $17.8 \%$ \\
- Prevalence of illicit sexual relation & 91 & $8.5 \%$ \\
\hline
\end{tabular}

\section{More than one response}

Table 1: demonstrates the prevalence of risk taking behaviors as responded by adolescents' students, it was found that $72.9 \%$ of students responded they didn't practice risk taking behaviors, $18.3 \%$ practicing one type only, while $8.8 \%$ of them practicing more than one type of risk taking behavior, $17.8 \%$ responding domestic violence, $8.5 \%$ of them illicit sexual relation and $7.4 \%$ reported smoking.

Table 2: Illustrates comparison between adolescents' students practicing and don't practicing the Risk Taking Behaviors according to their psychological profiles, statistically significant differences were found between students related to presents of anxiety and depression $\mathrm{P}=0$ 001, high score of anxiety was more prevent among students who practicing Risk Taking Behavior than those who don't (96.2\% and $89.6 \%$ ) respectively. High score of depression was observed among students who practicing RTB than those who don't practicing (84.8\% and $75.8 \%$ ) respectively. in addition the table revealed that students who practicing Risk Taking Behavior have low self-esteem than others (54.8\% and $49.4 \%$ respectively with no statistical significant difference.

Table 2: Comparison between Adolescents' Students Practicing and don't Practicing Risk Taking Behaviors according to their Psychological Profiles:

\begin{tabular}{|c|c|c|c|c|c|c|c|}
\hline \multirow{2}{*}{ Psychological Profiles: } & \multicolumn{2}{|c|}{$\begin{array}{l}\text { Practice Risk Taking Behavior. } \\
\qquad \mathrm{N}=290\end{array}$} & \multicolumn{2}{|c|}{$\begin{array}{c}\text { Do not Practice Risk Taking } \\
\text { Behavior. } \mathrm{N}=780\end{array}$} & \multicolumn{2}{|c|}{ Total $\mathrm{N}=1070$} & \multirow{2}{*}{$\begin{array}{l}X^{2} \\
\text { P. Value }\end{array}$} \\
\hline & No. & $\%$ & No. & $\%$ & No. & $\%$ & \\
\hline $\begin{array}{l}\text { Self-esteem } \\
\text { Low self -esteem } \\
\text { High self -esteem } \\
\text { Anxiety } \\
\text { No and mild anxiety } \\
\text { Moderate and Severe anxiety } \\
\text { Depression } \\
\text { Low depression score } \\
\text { High depression score }\end{array}$ & $\begin{array}{c}159 \\
131 \\
11 \\
279 \\
44 \\
246\end{array}$ & $\begin{array}{c}54.8 \% \\
45.2 \% \\
3.8 \% \\
96.2 \% \\
15.2 \% \\
84.8 \%\end{array}$ & $\begin{array}{c}385 \\
395 \\
81 \\
699 \\
189 \\
591\end{array}$ & $\begin{array}{l}49.4 \% \\
50.6 \% \\
10.4 \% \\
89.6 \% \\
24.2 \% \\
75.8 \%\end{array}$ & $\begin{array}{c}544 \\
526 \\
92 \\
978 \\
233 \\
837\end{array}$ & $\begin{array}{c}50.8 \% \\
49.2 \% \\
8.6 \% \\
91.4 \% \\
21.8 \% \\
78.2 \%\end{array}$ & $\begin{array}{c}0.11 \\
2.530 \\
11.687 \\
0.001^{\star} \\
10.183 \\
0.001^{\star}\end{array}$ \\
\hline
\end{tabular}

*Statistical significant differences

Table 3: Comparison between Adolescents' Students Practicing and don't Practicing Risk Taking Behaviors according to their Age and Parental Factors

\begin{tabular}{|c|c|c|c|c|c|c|c|}
\hline \multirow[t]{2}{*}{ Parental FACTORS } & \multicolumn{2}{|c|}{$\begin{array}{l}\text { Practice Risk Taking Behaviors } \\
\qquad \mathrm{N}=290\end{array}$} & \multicolumn{2}{|c|}{$\begin{array}{c}\text { Do not practice Risk Taking } \\
\text { Behaviors. } \mathrm{N}=780\end{array}$} & \multicolumn{2}{|c|}{$\begin{array}{c}\text { Total } \\
\mathrm{N}=1070\end{array}$} & \multirow[t]{2}{*}{$\begin{array}{c}\mathrm{X}^{2} \\
\text { P. Value }\end{array}$} \\
\hline & No. & $\%$ & No. & $\%$ & No. & $\%$ & \\
\hline $\begin{array}{l}\text { Age in years: } \\
13- \\
15- \\
17-18\end{array}$ & & $\begin{array}{c}56.9 \% \\
40 \% \\
3.1 \%\end{array}$ & & $\begin{array}{c}66.7 \% \\
36.7 \% \\
1.6 \%\end{array}$ & & $\begin{array}{c}60.4 \% \\
37.5 \% \\
2.1 \%\end{array}$ & $\begin{array}{c}3.544 \\
0.17\end{array}$ \\
\hline $\begin{array}{l}\text { Father education: } \\
\text { - Illiterate-read\& write } \\
\text { - Primary or preparatory level } \\
\text {-Secondary level } \\
\text { - University level }\end{array}$ & $\begin{array}{l}80 \\
45 \\
69 \\
96\end{array}$ & $\begin{array}{l}27.6 \% \\
15.5 \% \\
23.8 \% \\
33.1 \%\end{array}$ & $\begin{array}{l}201 \\
129 \\
190 \\
259\end{array}$ & $\begin{array}{l}25.8 \% \\
16.5 \% \\
24.4 \% \\
33.2 \%\end{array}$ & $\begin{array}{l}281 \\
174 \\
260 \\
355\end{array}$ & $\begin{array}{l}26.3 \% \\
16.3 \% \\
24.3 \% \\
33.1 \% \\
\end{array}$ & $\begin{array}{c}0.444 \\
0.93\end{array}$ \\
\hline $\begin{array}{l}\text { Mother education: } \\
\text { - Illiterate-read\& write } \\
\text { - Primary or preparatory level } \\
\text {-Secondary level } \\
\text { - University level }\end{array}$ & $\begin{array}{l}90 \\
40 \\
72 \\
88\end{array}$ & $\begin{array}{l}31.0 \% \\
13.8 \% \\
24.8 \% \\
30.3 \%\end{array}$ & $\begin{array}{l}266 \\
104 \\
198 \\
212 \\
\end{array}$ & $\begin{array}{l}34.1 \% \\
13.3 \% \\
25.4 \% \\
27.2 \%\end{array}$ & $\begin{array}{l}356 \\
144 \\
270 \\
300\end{array}$ & $\begin{array}{l}33.3 \% \\
13.5 \% \\
25.2 \% \\
28.0 \% \\
\end{array}$ & $\begin{array}{l}1.143 \\
0.70\end{array}$ \\
\hline \multirow[t]{2}{*}{ Parental FACTORS } & \multicolumn{2}{|c|}{$\begin{array}{l}\text { Practice Risk Taking Behaviors } \\
\qquad \mathrm{N}=290\end{array}$} & \multicolumn{2}{|c|}{$\begin{array}{c}\text { Do not practice Risk Taking } \\
\text { Behaviors. } \mathrm{N}=780\end{array}$} & \multicolumn{2}{|c|}{$\begin{array}{c}\text { Total } \\
\mathrm{N}=1070\end{array}$} & $\begin{array}{c}X^{2} \\
\text { P. Value }\end{array}$ \\
\hline & No. & $\%$ & No. & $\%$ & No. & $\%$ & \\
\hline $\begin{array}{l}\text { Father occupation: } \\
\text { Unemployed } \\
\text { Manual workers } \\
\text { Semiskilled\& skilled } \\
\text { Semiprofessional \& professional }\end{array}$ & $\begin{array}{c}31 \\
19 \\
31 \\
209\end{array}$ & $\begin{array}{c}10.7 \% \\
6.6 \% \\
10.7 \% \\
72.1 \%\end{array}$ & $\begin{array}{l}82 \\
69 \\
89 \\
540\end{array}$ & $\begin{array}{l}10.5 \% \\
8.8 \% \\
11.4 \% \\
69.2 \%\end{array}$ & $\begin{array}{c}113 \\
88 \\
120 \\
749\end{array}$ & $\begin{array}{c}10.6 \% \\
8.2 \% \\
11.2 \% \\
70.0 \%\end{array}$ & $\begin{array}{l}1.701 \\
0.64\end{array}$ \\
\hline
\end{tabular}




\begin{tabular}{|c|c|c|c|c|c|c|c|}
\hline $\begin{array}{l}\text { Mother occupation: } \\
\text { House wives } \\
\text { Working }\end{array}$ & $\begin{array}{c}216 \\
74\end{array}$ & $\begin{array}{l}74.5 \% \\
25.5 \%\end{array}$ & $\begin{array}{l}586 \\
194\end{array}$ & $\begin{array}{l}75.1 \% \\
24.9 \%\end{array}$ & $\begin{array}{l}802 \\
268\end{array}$ & $\begin{array}{l}75.0 \% \\
25.0 \%\end{array}$ & $\begin{array}{c}0.047 \\
0.83\end{array}$ \\
\hline $\begin{array}{l}\text { Family structure: } \\
\text { Living with their parents } \\
\text { Others \# }\end{array}$ & $\begin{array}{c}239 \\
51\end{array}$ & $\begin{array}{l}25.9 \% \\
34.9 \%\end{array}$ & $\begin{array}{c}685 \\
95\end{array}$ & $\begin{array}{l}76.1 \% \\
65.1 \%\end{array}$ & $\begin{array}{l}924 \\
146\end{array}$ & $\begin{array}{l}86.4 \% \\
13.6 \%\end{array}$ & $\begin{array}{c}5.243^{*} \\
0.02\end{array}$ \\
\hline $\begin{array}{l}\text { Parent student's communication: } \\
\text { Excellent } \\
\text { Fair } \\
\text { Poor }\end{array}$ & $\begin{array}{c}57 \\
164 \\
69\end{array}$ & $\begin{array}{l}19.7 \% \\
56.6 \% \\
23.8 \%\end{array}$ & $\begin{array}{l}258 \\
365 \\
157\end{array}$ & $\begin{array}{l}33.1 \% \\
46.8 \% \\
20.1 \%\end{array}$ & $\begin{array}{l}315 \\
529 \\
226\end{array}$ & $\begin{array}{l}29.4 \% \\
49.4 \% \\
21.2 \%\end{array}$ & $\begin{array}{l}18.351 \\
0.001^{*}\end{array}$ \\
\hline $\begin{array}{l}\text { Students satisfaction with their parents } \\
\text { relationship: } \\
\text { Satisfied } \\
\text { Not satisfied }\end{array}$ & $\begin{array}{l}184 \\
106\end{array}$ & $\begin{array}{l}23.9 \\
35.2\end{array}$ & $\begin{array}{l}585 \\
195\end{array}$ & $\begin{array}{l}76.1 \\
64.8\end{array}$ & $\begin{array}{l}769 \\
301\end{array}$ & $\begin{array}{l}71.9 \\
28.1\end{array}$ & $\begin{array}{l}13.953 \\
0.001^{*}\end{array}$ \\
\hline
\end{tabular}

*Statistically significant differences

\# Others means living with single parent or relatives.

Table 3: shows comparison between adolescents' students practicing and don't practicing Risk Taking Behaviors according to their age and parental factors, no statistical significant differences were found between adolescents who practicing and don't practicing Risk Taking Behaviors related to their age, parents' education and parents occupation. The majority of students (86.4\%) live with parents and students living in disrupted families (single parent family or with relatives) were significantly more engaged in practicing Risk Taking Behaviors than counterparts ( $34.9 \%$ versus $25.9 \%$ respectively), $p=0.02$. Regarding parents students relationship, this table also revealed that almost half of the students (49.4\%) stated that their parental communication was fair and $29.4 \%$ of them had excellent communication while $21.2 \%$ reported having poor communication. In addition to students who were not satisfied with their parents relationship constituted about $28.1 \%$. The prevalence of Risk Taking Behaviors was found to be significantly higher among students who were not satisfied with their parents than those who were satisfied (35.2\% versus $23.9 \%)$. $p<0.001$.

Table 4: Comparison between Adolescents' Students Practicing and don't Practicing Risk Taking Behaviors according to their Educational Factors

\begin{tabular}{|c|c|c|c|c|c|c|c|}
\hline \multirow[t]{2}{*}{ EDUCATIONAL FACTORS } & \multicolumn{2}{|c|}{$\begin{array}{c}\text { Practice Risk Taking } \\
\text { Behaviors } \\
N=290\end{array}$} & \multicolumn{2}{|c|}{$\begin{array}{c}\text { Do not practice Risk } \\
\text { Taking Behaviors } \\
\qquad \mathrm{N}=780\end{array}$} & \multicolumn{2}{|c|}{$\begin{array}{c}\text { Total } \\
\mathrm{N}=1070\end{array}$} & \multirow[t]{2}{*}{$\begin{array}{c}X^{2} \\
\text { P. Value }\end{array}$} \\
\hline & No. & $\%$ & No. & $\%$ & No. & $\%$ & \\
\hline $\begin{array}{l}\text { Type of education: } \\
\text { General education } \\
\text { Technical education }\end{array}$ & $\begin{array}{l}151 \\
139\end{array}$ & $\begin{array}{l}52.1 \% \\
47.9 \%\end{array}$ & $\begin{array}{l}499 \\
281\end{array}$ & $\begin{array}{l}64 \% \\
36 \%\end{array}$ & $\begin{array}{l}650 \\
420\end{array}$ & $\begin{array}{l}60.7 \% \\
39.3 \%\end{array}$ & $\begin{array}{c}12.566^{*} \\
0.001\end{array}$ \\
\hline $\begin{array}{l}\text { Educational Districts: } \\
\text { - Talkha district } \\
\text { - East district } \\
\text { - West district }\end{array}$ & $\begin{array}{c}112 \\
110 \\
68\end{array}$ & $\begin{array}{l}38.6 \% \\
38.0 \% \\
23.4 \%\end{array}$ & $\begin{array}{l}346 \\
237 \\
197\end{array}$ & $\begin{array}{l}44.4 \% \\
30.4 \% \\
25.2 \%\end{array}$ & $\begin{array}{l}458 \\
347 \\
265\end{array}$ & $\begin{array}{l}42.9 \% \\
32.4 \% \\
24.7 \%\end{array}$ & $\begin{array}{l}29.212^{*} \\
<0.001\end{array}$ \\
\hline $\begin{array}{l}\text { Previous scholastic failure: } \\
\text { Yes } \\
\text { No }\end{array}$ & $\begin{array}{c}62 \\
228\end{array}$ & $\begin{array}{l}21.4 \% \\
78.6 \%\end{array}$ & $\begin{array}{l}114 \\
666\end{array}$ & $\begin{array}{l}14.6 \% \\
85.4 \%\end{array}$ & $\begin{array}{l}176 \\
894\end{array}$ & $\begin{array}{l}16.4 \% \\
83.6 \%\end{array}$ & $\begin{array}{c}7.038^{\star} \\
0.008\end{array}$ \\
\hline $\begin{array}{l}\text { Teacher student's communication } \\
\text { according to students response: } \\
\text { Excellent } \\
\text { Fair } \\
\text { Poor }\end{array}$ & $\begin{array}{c}50 \\
189 \\
51\end{array}$ & $\begin{array}{l}17.2 \% \\
65.2 \% \\
17.6 \%\end{array}$ & $\begin{array}{c}189 \\
514 \\
77\end{array}$ & $\begin{array}{c}24.2 \\
65.9 \% \\
9.9 \%\end{array}$ & $\begin{array}{l}239 \\
703 \\
128\end{array}$ & $\begin{array}{c}22.3 \\
65.7 \\
12.0 \%\end{array}$ & $\begin{array}{c}15.157^{*} \\
0.001\end{array}$ \\
\hline $\begin{array}{l}\text { Student satisfaction toward teachers relation: } \\
\text { Completely satisfied } \\
\text { Partially satisfied } \\
\text { Not satisfy }\end{array}$ & $\begin{array}{l}95 \\
98 \\
97\end{array}$ & $\begin{array}{l}32.8 \% \\
33.8 \% \\
33.4 \% \\
\end{array}$ & $\begin{array}{l}253 \\
323 \\
204\end{array}$ & $\begin{array}{l}32.4 \% \\
41.4 \% \\
26.2 \% \\
\end{array}$ & $\begin{array}{l}348 \\
421 \\
301 \\
\end{array}$ & $\begin{array}{l}35.5 \% \\
39.3 \% \\
28.1 \% \\
\end{array}$ & $\begin{array}{c}7.123^{*} \\
0.03\end{array}$ \\
\hline $\begin{array}{l}\text { Peers practicing of Risk Taking Behaviors; } \\
\text { Yes } \\
\text { No }\end{array}$ & 27218 & $\begin{array}{c}93.8 \% \\
6.2 \%\end{array}$ & $\begin{array}{l}304 \\
476\end{array}$ & $\begin{array}{l}39.0 \% \\
61.0 \%\end{array}$ & $\begin{array}{l}576 \\
494\end{array}$ & $\begin{array}{l}53.8 \\
46.2\end{array}$ & $\begin{array}{r}255.614^{*} \\
<0.001\end{array}$ \\
\hline
\end{tabular}

*Statistically significant differences

Table 4: shows comparison between adolescents' students practicing and don't practicing Risk Taking Behaviors according to their educational factors, statistically significant differences were found between students who practicing Risk Taking Behaviors and those who do not practicing related all items related to educational factors in the table. Risk Taking Behaviors was prevalent among students in the technical education $P=0.001$, east district $P=0.001$, had previous scholastic failure $p=0.008$, poor teacher students communication $\mathrm{P}=0.001$ unsatisfying from teacher relation $\mathrm{P}=0.03$ and have peers practicing Risk Taking Behaviors $\mathrm{P}=0.001$ than students who don't practicing Risk Taking Behaviors. 
Table 5: Comparison between a adolescents' Students Practicing and don't Practicing Risk Taking Behaviors according to the Community Factors.

\begin{tabular}{|c|c|c|c|c|c|c|c|}
\hline \multirow[t]{2}{*}{ COMMUNITY FACTORS } & \multicolumn{2}{|c|}{$\begin{array}{c}\text { Practice Risk Taking } \\
\text { Behaviors } \\
\mathrm{N}=290\end{array}$} & \multicolumn{2}{|c|}{$\begin{array}{l}\text { Do not practice Risk } \\
\text { Taking Behaviors } \\
\qquad N=780\end{array}$} & \multicolumn{2}{|c|}{$\begin{array}{c}\text { Total } \\
\mathrm{N}=1070\end{array}$} & \multirow[t]{2}{*}{$\begin{array}{c}X^{2} \\
\text { P. Value }\end{array}$} \\
\hline & No. & $\%$ & No. & $\%$ & No. & $\%$ & \\
\hline $\begin{array}{l}\text { Asking for advice: } \\
\text { Yes } \\
\text { No }\end{array}$ & $\begin{array}{c}210 \\
80\end{array}$ & $\begin{array}{l}72.4 \% \\
27.6 \%\end{array}$ & $\begin{array}{l}669 \\
111\end{array}$ & $\begin{array}{l}85.8 \% \\
14.2 \%\end{array}$ & $\begin{array}{l}879 \\
191\end{array}$ & $\begin{array}{l}82.2 \\
17.8\end{array}$ & $\begin{array}{c}25.714^{*} \\
<0.001\end{array}$ \\
\hline $\begin{array}{l}\text { Search for knowledgerelated Risk Taking Behaviors: } \\
\text { Yes } \\
\text { No }\end{array}$ & 24347 & $\begin{array}{l}83.8 \% \\
16.2 \% \\
\end{array}$ & $\begin{array}{l}555 \\
225 \\
\end{array}$ & $\begin{array}{l}71.2 \% \\
28.8 \% \\
\end{array}$ & $\begin{array}{l}798 \\
272 \\
\end{array}$ & $\begin{array}{l}74.6 \% \\
25.4 \% \\
\end{array}$ & $\begin{array}{l}17.813^{*} \\
<0.001\end{array}$ \\
\hline $\begin{array}{l}\text { Practicing unplanned activities: } \\
\text { Yes } \\
\text { No }\end{array}$ & $\begin{array}{c}212 \\
78\end{array}$ & $\begin{array}{l}73.1 \% \\
26.9 \%\end{array}$ & $\begin{array}{l}422 \\
358\end{array}$ & $\begin{array}{l}54.1 \% \\
45.9 \%\end{array}$ & $\begin{array}{l}634 \\
436 \\
\end{array}$ & $\begin{array}{l}59.3 \% \\
40.7 \%\end{array}$ & $\begin{array}{l}31.612^{*} \\
<0.001\end{array}$ \\
\hline
\end{tabular}

* Statistical Significant differences

\# Internet café for chatting, unsupervised walking in groups, driving cars without license or teasing other sex.

Table(5): notes comparison between adolescents' students practicing and don't practicing Risk Taking Behaviors according to community factors, statistically significant differences were found between students who practicing Risk Taking Behaviors and those who don't practicing related all items in of community factors listed in the table, students who practicing Risk Taking Behaviors responded that they didn't ask for advice, they search for knowledge related Risk Taking Behaviors and practicing unplanned activities as Internet café for chatting, unsupervised walking in groups, driving cars without license or teasing other sex. $P=0.001$.

\section{Discussion}

Adolescence is a crucial period that bridges childhood and adulthood, hence it encompasses the critical life decisions and developmental tasks [22]. Adolescence years are a time of preparation for taking responsibilities, exploration and widening horizons and a time to promote their health [23]. Accordingly, adolescence is a developmental period characterized by behaviors that involve taking risks. Healthy adolescent risk taking behaviors which tend to have a positive impact on an adolescent's development, include; participation in sports, the development of artistic and creative abilities, travel and constructive contributions to the family or community. On the other hand, adolescent risk-taking becomes unhealthy or negative when the risks are dangerous [24]. The present study showed that about $27 \%$ of the female secondary school students were practicing unhealthy Risk Taking Behaviors as shown in Table 1. Teenagers mostly take risks as a normal part of growing up and as a tool to define and develop their identity $[6,18]$. The most common reasons for adoption of Risk Taking Behaviors among adolescents student may be peer acceptance alleviate tension and stress, a sign of masculinity and personal freedom and self-confidence.

Risk taking behaviors don't occur in isolation; rather they tend to cluster in somewhat ways. Overtime, involvement in one type of risk has been found to increase the likelihood of becoming involved in other risk behavior [25]. For example, the use of illicit drugs is linked with problem behaviors such as violence and early sexual activity with its bad consequences [18]. The present study revealed that $18.3 \%$ of adolescent students were practicing one type of Risk Taking Behaviors while $8.8 \%$ of them were practicing more than one type as shown in Table 1. Accordingly, early intervention will prevent this clustering with its bad squeal [26].

The present study revealed that physical fights had the highest prevalence of risk taking behaviors (17.8\%) in domestic violence as shown in Table 1.Abu Nazal et al. (2013), study in Dakahlia, reported a lower figure $(9.4 \%)$ for physical bulling among high school students [27]. This is in accordance with other studies, which declared that violence, in school, is an increasing this problem worldwide [21,22]. The recent international report (2015) of the Health Behavior in School (HBSC) students showed that rates of bulling, worldwide, were ranged from $10-50 \%$. In the US Morbidity and Mortality Weekly Report about students, 33\% had physical fights [28]. This high violence rate was attributed to the stress of entrance to high school [29]. Physical violence is a prominent cause of injury and homicide, which contribute to potential life loss [28]. So, antiviolence strategy, as an intervention program, is urged to prevent the serious consequences. This can be achieved through assisting students to develop self-competency, good relationships with others besides the strong social skills.

During adolescence, there is a gradual move from involvement with groups of the same sex to mixed groups, and sexual pairing may take place. In US and UK, where nearby half of high school students had sexual intercourse associated with high rates of teenage pregnancy [29,30]. In a study done in Nigeria, showed that by the age of 13 years, over a quarter of the students were sexually active [31]. In Eastern culture and Islamic countries, tackling the issue of sexual behavior is somewhat critical and limited Egyptian studies explore this behavior. The current study found that $8.5 \%$ of the students were involved in illicit sexual relation as shown in Table 1.

Smoking is a common and a widely practiced social habit and continues to be a significant problem among adolescents. A survey conducted in USA, among high school students in the year 2010, found that the prevalence of current cigarette use was $21.9 \%$ [32]. In Germany during the year 2008 [33], it was found that $30 \%$ of $9^{\text {th }}$ grade students were current smokers. Among Arab countries, the prevalence of smoking, among high school students, in Saudi Arabia was $13.2 \%$, in Yemen was $19.6 \%$, and in Bahrain was $26.6 \%$ [34,35,36]. The 
present study showed that the prevalence rate of current smoking was $7.4 \%$ as shown in Table 1 . Lower rate $(6 \%)$ of current smoking in Egypt was reported by Ibrahim et al. (2011) [24]. These variations of the reported rates of smoking are not uncommon. These differences could be explained by the different methodological issues, social acceptance to report about smoking habit, economic standard, tradition or cultural conditions prevailing in different communities.

Since smoking is the royal gate to drug use, a strong correlation between smoking and illicit drug use was confirmed by Al- Haddad\& Hamadeh [37]. Worldwide, illicit drug use started to be reported among adolescents. A survey conducted in US (2012) [38], showed that $37 \%$ of those aged 12 years and older had tried marijuana. In UK, Henry et al and Bethesda showed that $29 \%$ of boys and $25 \%$ of girls aged 14 15 years old had tried cannabis [39,40]. In Brazil, a study carried-out among students of age 10 to 18 years revealed that alcohol use was $15 \%$, marijuana was $7.6 \%$ and cocaine was $2 \%$ [41]. In the present study, students who confessed that they were experimenting illicit drugs were estimated to be $6.2 \%$ and marijuana (hashish) was found to be the most prevalent (98.5\%) substance abuse among them. The differences between countries regarding the prevalence and the type of drugs may be due to cultural, religious variation, availability and easiness of getting drugs. Moreover, the most common source of drug and previous information about it were attributed to the peer.

Negative peer pressure was the most dominated mediator in the onset and maintenance of smoking and illicit drug use $[42,43]$. In the present study, analyses revealed that peers adoption of risk taking behaviors is a statistically significant factor related to practice of risk taking behaviors among students as shown in Table 4. This finding is consistent with those from previous studies Guo et al in (2012) found that the effect of family bounding began to decrease after the age of 18 years and the effect of peers' antisocial activity started to increase after the age of 15 years. It was implicated that the effort to prevent illicit drug initiation, as an example of risk taking behavior, should start early, focusing on family bonding and continue into the twenties, focusing on peer factors. Family monitoring, supervision and control remain important factors throughout adolescence [42]. This is in consistent with the study of Glantz and Leshner (2009) which showed that the initiation and escalation of drug use is often a result of the interaction between individual factors (such as genetic predisposition and childhood psychopathologies) and environmental factors (such as family and peer influences).

It was reported that once smoking has begun in adolescence, it is likely to be a long-term addiction as it will be incorporated in their life style, so its cessation is difficult. Accordingly, prevention of the onset of adolescent smoking is an essential component of effort to reduce the overall prevalence of smoking and its attendant morbidity and mortality. Regarding illicit drug, El-Akabawi, in Egypt 2009 [43], reported that the age of 20 years showed rising rate of drug abuse. As health related behaviors are usually established in childhood, it was recommended that positive alternative healthy behaviors need to be promoted during primary education level, before damaging behaviors are initiated.

It is fundamental to remember that adolescents risk taking behaviors is viewed as the result of a number of complex factors. Hence, interventions that may reduce risk taking behaviors must be based on the complex multifaceted nature rather than narrowly focused on only one or two factors [8].

Psychological factors are thought to play an important role in health related aspects of teenage behavior $[41,42]$. The present study revealed that high scores of both anxiety and depression were significantly related to risk taking behaviors among students as shown in Table 2. This may be due to restricted activities for girls in comparison to boys after puberty, may affect their psychological profile.

The present study revealed that the prevalence of risk taking behaviors was significantly higher among students who didn't ask for advice. On the other hand, students who search for knowledge about the period of adolescence were more practicing risk taking behaviors as shown in Table 5. This is verified by the finding that the majority of students (more than $80 \%$ ) who were either smoker or illicit drug user mentioned that they had obtained information about its bad health consequences [40] So, we can say that knowledge about the health effects of both smoking and drug use appears to have no effect or doesn't offer protection. It is not readily apparent why health knowledge seems to be generally accepted as important, but yet does not appear to influence behavior as expected. This necessitates the provision of advice and sources of knowledge in a way helping the students to be active participants and not passively receivers to change their attitudes and at the same time counteract the effects of other risk factors.

As for social characteristics, the present study revealed that a significantly higher percentage of students who didn't live with both parents were practicing risk taking behaviors than those who live with their parents as shown in Table 3. This may be attributed to the disturbed family. On the other hand, the present study revealed that excellent communication with both parent and teachers or to a greater extent the adolescents' satisfaction of their relation with others, were significantly reducing risk taking behaviors. This can be due to the direct effect of close monitoring of adolescent's behavior, the strong bond, the warm and supportive environment or the indirect effect of decreasing the adolescent's association with peers [36]. Since adolescence is a period of significant change for a person (sexual, physical, emotional, and behavioral), strong guidance from parents and teachers can help to overcome these stressful and new experiences. Often, the biggest conflict, the adolescents have with their parents, is that they are expected to act like adults but they are treated as children. Parents who have positive communication with their adolescents can help them to experience the independent decision making [39]. Moreover, the finding of the present study revealed that risk taking behaviors were significantly more encountered among students who had previous scholastic failure as shown in Table 4.

This may be due to factor as unsatisfaction with teachers 
and parents relations.

\section{Conclusion}

The cross sectional survey, among adolescent students, showed that risk taking behaviors, such as domestic violence, illicit sexual relation, smoking and substance abuse, were prevalent. Hence, adolescence must be considered as a time of risk. The factors which are significantly associated with adolescent risk taking behaviors were; family structure, satisfaction of adult adolescent relationship, educational zones, scholastic achievement, peers adoption of risk taking behaviors asking for advice and practicing of unplanned activities.

\section{Recommendations}

1. Better communication and interpersonal relationship between adults and adolescent in order to listen and discuss all adolescent problems and to encourage active participation.

2. Help adolescents to adopt life skills techniques through collaboration with parents, schools and the community to support and help them how to manage daily faced stressors and consequently reduce the risk of adoption of risk taking behaviors.

3. Further research by controlled studies which are based on the theory directed toward understanding why some adolescents practice risk taking behaviors and others do not, taking into consideration the factors having significant effects.

4. Development of early preventive interventions programs that depend on the function of protective factors either in one way as the presence of these factors or the absence or low level of risk factors.

5. The dominant influence of peers must be an important issue for developing effective anti-risk taking behaviors campaigns directed at adolescence period.

Conflict of interest: The authors confirm that there is no conflict of interest regarding this manuscript.

\section{References}

1. Gardner $M$, and Steinberg L. Peer Influence on Risk Taking, Risk Preference, and Risky Decision Making in Adolescence and Adulthood: An Experimental Study. J. Dev. Psychol. 2013; 14(4): 625-635. doi: 10.1037/0012-1649.41.4.625

2. Jamsiah $M$, Hazlinda $H$. Factor affecting social misconduct amongst adolescent in Melaka Tengah District. J. Commu. Health. 2009; 15(1): 21-31.

3. Hidayah $\mathrm{NI}$, Hanafiah MS, Idris MN. Risk taking behavior among adolescent in Johor Bahru and its associated factor. J. Commu. Health. 2003; 9: 12-20.

4. Machteld $H$, Judith SD, Wilma $S$, et al. The relationship between parenting and delinquency: a meta-analysis. J. Abnorm. Child. Psychol. 2009; 37(6): 749-75. doi: 10.1007/s10802-009-9310-8

5. Topolski TD, Patrick DL, Edwards TC, Huebner, CE, Connell FA, et.al. Quality of Life and Health-Risk Behaviors among Adolescents. J. Adolesc. Health. 2011; 29(6): 426-35.
6. Okorodudu G. Influence of parenting styles on adolescent delinquency in Delta Central Senatorial District [Thesis PhD]. Institute of Education Delta State University, Abraka; 2010.

7. Nelson BV, Patience TH, Macdonald DC. Adolescent risk behavior and influence on parental \& education. J. Am. Board .Fam. Pract. 1999; 12(6): 436-43.

8. CAPMAS: The state of Egyptian children and women. CAPMAS and UNICEF, Cairo, Egypt, 2015; 17.

9. Rahmah MA, Shahriza B. Risk taking behavior among adolescents in Johor Bahru and its associated factor. J. Commu. Health. 2008; 14(2): 24-30.

10. Palamara P, Molnar L, Eby D, Kopinanthan C, Langford J, et.al. Review of Young Driver Risk Taking and Its Association with Other Risk Taking Behaviors. 2012.

11. Elkind D. Development of the Child. 1978.

12. Arnett J. Reckless Behavior in Adolescence: a Developmental Perspective. Dev. Rev. 2011; 12(4): 339-73. doi : 10.1016/0273-2297 (92)90013

13. Lightfoot $C$. The Culture of Adolescent Risk-taking. New York: Guildford. 2008.

14. Haddad LG, Owies A, Mansour A. Wellness Appraisal among Adolescents in Jordan: A Model from a Developing Country: A Cross-Sectional Questionnaire Survey. Health. Promot. Int. 2009; 24(2): 130-139. doi: 10.1093/heapro/dap013

15. Karen $L B$, Hyman $H$, et.al. Preventing drug use among children and adolescents. National Institutes of Health. 2002.

16. Kann, Steve K, Shari L. Youth Risk Behavior Surveillance-United States, Morbidity and Mortality Weekly Report (MMWR). 2013; 63 (04):1-168.

17. Ryden MB. A children version of the Coopersmith Self-Esteem Inventory: Test-retest reliability and social desirability. Psychol. Reports. 1978; 43:1189-1190.

18. Taylor J. A personality scale of manifest anxiety. J Abnorm. Psychol. 1953; 48 (2): 285-290. doi: 10.1037/h0056264

19. Nilsson $M$, Whitehall $L$, Barnstorm $E$, Sherlund $H$, Janlert U. Adolescent's Perceptions and Expectations of Parental Action on Children's Smoking and Snus Use; National Cross Sectional Data from Three Decades. BMC. Public. Health. 2009 ; 9(74): doi: 10.1186/1471-2458-9-74

20. Child Trends Data Bank. 2012.

21. Ibrahim B, Sallam S, El Sahn F, El Tawila S, El Gibaly O, et.al. Transition to Adulthood: A National Survey of Egyption Adolescents. 2011.

22. Sleep Medicine Clinic/Lab. Proper sleep is essential to good health.

23. Robinson AJ, Rogstad K. Adolescence a time of risk taking. J. Sex. Trasm. Infect. 2002; 78(5) : 314-15. doi: 101136/sti.78.5.314

24. Brener ND, Collims JL. Co-occurrence of health - risk behaviors among adolescents in the United States. J. Adolesc. Health. 1998; 22 (3): 209-13. doi: 10.1016/S1054-139X(97)00161-4

25. Abu NM, Mahdy NH. Predictors of bullying and victimization behavior among secondary school students in Dakahlia Governorate 2013.

26. International report. Young people's health in context: selected key findings from the Health Behavior in School - aged Children study. Fact sheet EURO. 2015.

27. Youth Risk Behavior Surveillance- United States. MMWR 2013 / 2014; 53: 1- 8

28. Espelage $\mathrm{DL}$, Hot MK. Bullying and victimization during early adolescence: Peer influence and psychosocial correlates. J. Emotional. Abuse. 2001; 2(3): 123-42. doi: 10.1300/j135v02n02_08

29. Gruber E, Grube JW. Adolescent sexuality and the media: a review of current knowledge and implications. West. J. Med. 2009; 172(3): 210-24.

30. Wight $D$, Raab GM, Handerson M, Abraham C, Buston K, et.al. Scott $S$ Limits of teacher delivered sex education. Interim behavioral outcomes from randomized trial. BMJ. 2008; 234: 1430.

31. Cigarette use among high school students- United States. Center for Disease Control and Prevention. 1991-2003. MMWR 2007; 53(23): 449-502. 
32. Kraus B, Wodarz N, Kuchlmaier K, Kliegel $\mathrm{P}$, Binder $\mathrm{H}$, et.al. Use of Cigarettes, Alocohl and Drugs by Adolescents- A Questionnaire Survey among $9^{\text {th }}$ Grade Students. Psychiatr. Prax. 2004; 31(1): 99-101. doi: $10.1055 / \mathrm{s}-2004-828446$

33. Jarallah JS, Bamqboye EA, al-Ansary LA, Kalantan KA. Predictors of smoking among male junior secondary school students in Riyadh, Saudi Arabia. Tob. control. 1996; 5(1): 26-9.

34. Bawazeer AA, Hattab AS, Morales E. Cigarette smoking experience among secondary- school students in Aden, Republic of Yemen Eastern. East. Mediterr. Health. J. 1999; 5(3): 40-9.

35. $\mathrm{Al}-\mathrm{HN}$, Hamadeh RR. Smoking among secondary - school boys in Bahrain: prevalence and risk factors. East. Mediatrr. Health. J. 2003; 9(12): 78-86.

36. Bethesda MD. Marijuana abuse. National institute on drug abuse 2012.

37. Henry JA, Oldfield WL, Kon OM. Comparing cannabis with tobacco. BMJ. 2003; 326(7396): 942 - 43. doi: 10.1136/bmj.326.7396.942
38. Galduroz JC, Noto AR, Nappo SA, Carlini EA. Trends in drug use among students in Brazil: analysis or four surveys in 1987, 1989, 1993 and 1997. Braz. J. med. Biol. Res. 2004; 37(4): 523-31. doi: 10.1590/\$0100-879X2004000400009

39. Smet B, Maes L, De Clercq L, Haryanti K, and Djati WR. Determinants of smoking behavior among adolescents in Semarang, Indonesia. Tob. Control. 1999; 8(2): 186-191.

40. Guo J, Hill KG, Hawkins JD, Catalano RF and Abbott RD. A developmental analysis of socio-demographic, family, and peer effects on adolescent illicit drug initiation. J. Am. Academy. Child. Adolesc. Psychiatry. 2002; 41(7): 838-45. doi: 10.1097/00004583-200207000-00017

41. Hawkins JD, Catalano RF, Kosterman R, Abbott RD, Hill KG. Preventing adolescent health risk behaviors by strengthening protection during childhood. Arch. Pediatr. Adolesc. Med. 1999; 153(3): 226-234.

42. Glantz MD, Leshner Al. Drug abuse and developmental psychopathology. Dev. Psychopathol. 2000; 12(4): 795-814.

43. El- Akabawi AS. Drug abuse in Arab World: A country profile of Egypt. In Okasha A, Maj M. An Arab perspective. 